\title{
367 ノードレスハイブリッド要素の提案と位相最適化問題への適用
}

Proposal of nodeless hybrid element and its application to topology optimization problem

○藤井大地（東京大），正 北山光也，正 鈴木克幸（東京大）

正 大坪英臣 (東京大), 正 風間悦夫, 正 川井忠彦

Daiji FUJII, The University of Tokyo, 7-3-1, Hongo Bunkyo-ku, Tokyo

Mitsunari KITAYAMA, Nagano College of Technology

Katsuyuki SUZUKI, The University of Tokyo

Hideomi OHTSUBO, The University of Tokyo

Etsuo KAZAMA, Nagano College of Technology

Tadahiko KAWAI, Science University of Tokyo

Key Words : Nodeless hybrid element, Stress assumed element, Topology optimization, Homogenization design method, Checkerboards,

\section{1.はじめに}

近年, 有限要素解析におけるモデリングの労力を低減する ため, 自動メッシュ生成法, メッシュレス法, アダプティブ 法等, 様々なアプローチが試みられている.しかしながら， 特に亀裂等の不連続面を有する解析では, 依然モデリングの 労力は多大なものであり,このような問題に対するブレーク スルーが求められている。 これに対して, 川井, 風間, 北山 らは，一連の論文 ${ }^{1), 2)}$ で，節点の概念を用いないノードレス 法を提唱している.ノードレス法では，節点を用いないため メッシュ生成に自由度が生まれ，また，節点を用いるために 生じる問題点を解決できる、そこで，本論文では，ノードレ ス法の考え方をハイブリッド法に応用し, 応力仮定法にもと つくノードレスハイブリッド要素を提案する. そして，この 要素を位相最適化問題に適用することにより，節点を用いる ことによって生じる問題を解決できることを示す.

\section{2. ノードレスハイブリッド要素の定式化}

ノードレス法 ${ }^{1), 2)}$ では, Fig.1 に示すように一つの要素 $k$ と 辺を共有する周辺要素 $(k, 1) \sim(k, 4)$ の平衡条件と連続条件 を考えることによって定式化を行う．ここでは，ハイブリッ ド法 ${ }^{3)}$ の考え方にもとづき，境界反力をラグランジェ乗数と して独立に定義し, 境界の変位の連続性を積分的に満足させ るものとする．この場合，要素 $k$ に関して次式が成り立つ.

$$
-\int_{\nu^{\prime}} \sigma_{i j, J}^{k} \delta u_{i}^{k} d V+\sum_{l=1}^{4} \int_{s^{u}}\left(u_{i}^{(k, l)}-u_{i}^{k}\right) \delta \lambda_{i}^{k l} d S=0
$$

ここに， $\sigma_{i j}$ は応カテンソル， $u_{i}$ は変位ベクトル， $\lambda_{i}$ はラグ ランジェ乗数 (境界反カベクトル) である. また， $V$ は要素 領域, $S$ は要素境界を表し, 各変数の上添字は, 要素および 境界の記号を表す。なお，物体力は無視している.

(1)式の第 1 項をガウスの発散定理を用いて部分積分する と次式のようになる.

$$
\int_{\gamma^{\prime}} \sigma_{i j}^{k} \delta \varepsilon_{i j}^{k} d V-\sum_{i=1}^{4} \int_{S^{\prime \prime}} \lambda_{i}^{k t} \delta u_{i}^{k} d S+\sum_{l=1}^{4} \int_{s^{u}}\left(u_{i}^{(k, l)}-u_{i}^{k}\right) \delta \lambda_{i}^{k l} d S=0
$$

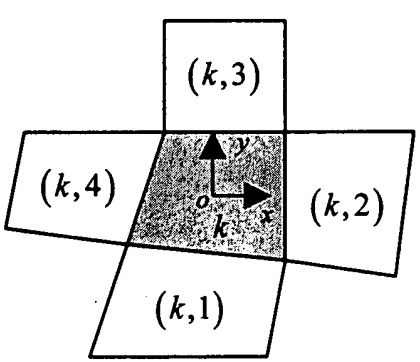

Fig.1 $k$-th element and its neighbor elements

2 次元平面問題に関して(2)式を離散化する. まず，态力仮 定法の考え方 ${ }^{4}$ により，変位と応力を次式のように仮定する.

$$
\begin{aligned}
& u_{x}=a_{11}+a_{12} x+a_{13} y+a_{14} x y \\
& u_{y}=a_{21}+a_{22} x+a_{23} y+a_{24} x y \\
& \sigma_{x}=c_{11}+c_{12} y, \quad \sigma_{y}=c_{21}+c_{22} x, \quad \tau_{x y}=c_{31}
\end{aligned}
$$

また，ラグランジェ末定乗数（境界反力）は, 各辺上で一定 であると仮定し，次式のように置く．

$$
\lambda_{x}=r_{1}, \quad \lambda_{x}=r_{2}
$$

(3), (4)式をべクトル・マトリックスで表すと,

$$
\mathbf{u}=\mathbf{N A}, \quad \boldsymbol{\sigma}=\mathbf{N}_{s} \mathbf{C}, \quad \lambda=\mathbf{N}_{\lambda} \mathbf{R}
$$

ここに, A, C, R は末定係数べクトルである.

(5)式の第 1 式を歪み一変位関係式に代入すると,

$$
\tilde{\boldsymbol{\varepsilon}}=\mathbf{B A}
$$

一方，(5)式の第 2 式を忘力ー歪み関係式に代入すると，

$$
\varepsilon=\mathbf{D}^{-1} \mathbf{N}_{s} \mathbf{C}
$$

ここに，Dは弾性マトリックス．応力仮定法では，(6)式と(7) 式が要素領域内で次式を満足するものとする.

$$
\int_{V^{k}} \delta \sigma(\varepsilon-\tilde{\varepsilon}) d V=0
$$

上式に，(5)式の第 2 式と(6), (7)式を代入して解くと， 


$$
\begin{gathered}
\mathbf{C}=\mathbf{M}_{s}{ }^{-1} \mathbf{M}_{B} \mathbb{A} \\
\mathbf{M}_{s}=\int_{t^{2}} \mathbf{N}_{s}{ }^{T} \mathbf{D}^{-1} \mathbf{N}_{s} d V, \quad \mathbf{M}_{B}=\int_{y^{k}} \mathbb{N}_{s}{ }^{T} \mathbb{B} d V
\end{gathered}
$$

(9)式を(5)式の第 2 式および(7)式に代入することにより，応 カおよび歪みベクトルは次式のように表される.

$$
\sigma=\mathbf{N}_{s} \mathbf{M}_{s}^{-1} \mathbf{M}_{B} A, \quad \varepsilon=D^{-1} \mathbf{N}_{s} M_{s}^{-1} M_{B} A
$$

以上から，(2)式は次式のように離散化される。

$$
\begin{aligned}
& \delta \mathbf{A}^{k^{T}} \mathbf{M}_{B}{ }^{T} \mathbf{M}_{S}{ }^{-1} \mathbf{M}_{B} \mathbf{A}^{k}-\delta \mathbf{A}^{k^{T}} \sum_{i=1}^{4} \int_{\delta^{u}} \mathbf{N}^{T} \mathbf{N}_{\lambda} d S \mathbf{R}^{k t} \\
& +\delta \mathbf{R}^{\mu^{T}}\left(\sum_{l=1}^{4} \int_{\delta^{u}} \mathbf{N}_{\lambda}{ }^{T} \mathbf{N} d S \mathbf{A}^{(k, l)}-\sum_{l=1}^{4} \int_{\delta^{u}} \mathbf{N}_{\lambda}{ }^{T} \mathbf{N} d S \mathbf{A}^{k}\right)=0
\end{aligned}
$$

(12)式から要素の方程式を作りここれをすべての要素につい て重ね合わせると，次式のような全体剛性方程式を得る.

$$
\left[\begin{array}{cc}
\mathbf{K} & \mathbf{Q} \\
\mathbf{Q}^{T} & \mathbf{0}
\end{array}\right]\left\{\begin{array}{l}
\mathbf{A} \\
\mathbf{R}
\end{array}\right\}=\left\{\begin{array}{l}
0 \\
0
\end{array}\right\}
$$

上式に離散化した荷重・境界条件を付加して解く.

\section{3. 位相最適化問題への適用例}

連続体の位相最適化問題では, 解に疎, 密な密度分布が交 互に並ぶチェッカーボード分布がしばしば現れる。これは数 值的な問題であり ")，節点を介して変位の連続性を考慮する 有限要素法の問題点でもある.

このことを示すために，以上に示したノードレスハイブリ ッド要素を用いて，Fig.2 に示す位相最適化問題を解く．位 相最適化の手法としては，均質化設計法 ${ }^{6}$ を用いる。解析は 対称性を利用して $1 / 2$ 領域で行う．有限要素メッシュは $1 / 2$ 領域で $64 \times 20$ とした．また，体積制約は 50\%に設定した.

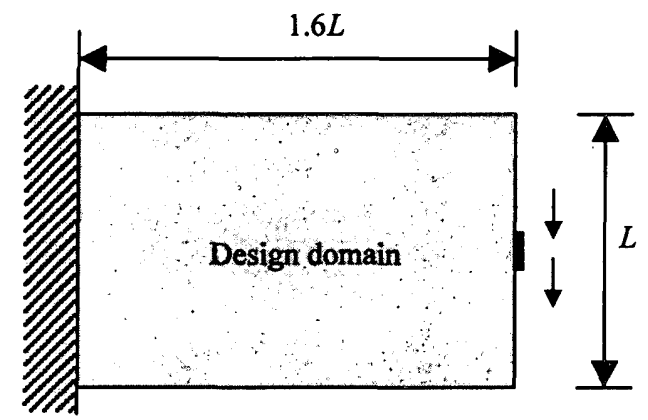

Fig.2 Design domain of topology optimization of cantilever plate

Fig.3 は，4節点アイソパラメトリック要素を用いた場合の 結果を示し，Fig.4 は，本論文で提案した要素を用いた場合 の結果を示している. 図から，Fig.3 で現れていたチェッカ 一ボード状の密度分布は，Fig.4 では完全に消えていること がわかる.このように，本論文に示した要素では，要素間の 連続性が積分的に満足されるため, チェッカーボード現象は 生じない. Fig.5 は, さらに鈴木 ${ }^{6}$ の提案したフィルタリング 法》を用いたもので，この場合，チェッカーボードの無い明 解な位相が求まることがわかる.

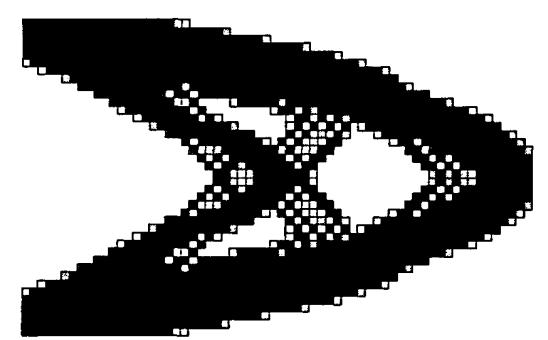

Fig.3 Optimum topology (iso-parametric element)

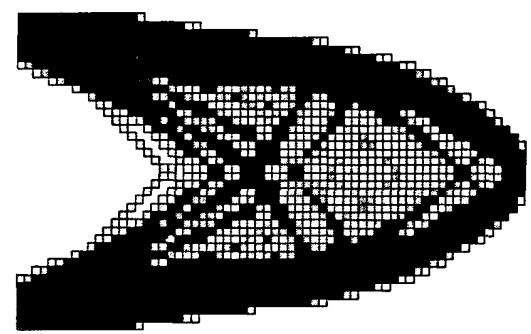

Fig.4 Optimum topology (the present element)

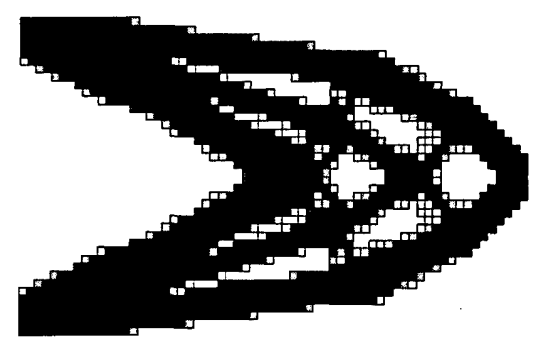

Fig.5 Optimum topology (the present element with filtering)

4. まとめ

本論文では, 応力仮定法にもとつくくノドレスハイブリッ ド要素を提案し，位相最適化問題に適用することで, ノード レスの有利点の一端を示した.

\section{参考文献}

1) 川井忠彦, 固体力学問題の新しい離散化解析法の開発, 日本機械学会材料力学部門講演会論文集, A(98-5)(1998) 25-28

2) 風間悦夫, 北山光也, 川井忠彦, 新しい離散化解析法の 実用化に関する研究( I ) (V), 計算工学講演会論文集, 4(1)(1999), 5(1)(2000)

3） Zienkiewicz, O.C. and Taylor, R.L.著, 矢川元基監訳, マト リックス有限要素法 I , 科学技術出版社, (1996) 376-379

4) 関口美奈子, 菊池昇, 混合的な有限要素剛性マトリック スの導き方に関する一考察－Clough 1960 年の論文を中 心として一，計算工学講演会論文集，4(1) (1999) 131-134

5) Diaz, A. and Sigmund, O., Checkerboard patterns in layout optimization, Structural Optimization, 10(1995) 40-45

6) K. Suzuki and N. Kikuchi : A homogenization method for shape and topology optimization, Computer Methods in Applied Mechanics and Engineering, Vol.93, pp.291-318, 1991

7）石井恵三, 青村茂, 菊池昇, フレームベースユニットセ ルを用いた位相最適化の研究，日本機械学会論文集（C 編)，67(654) (2001) 209-216 